\title{
Toward a discursively oriented historical sociology of the modern
}

There is no single narrative, let alone explanation, of modernity. Being and becoming modern is contested and renegotiated over time and there is no widely accepted understanding of what it means to be modern (Flatley 2008). What we have instead is a constant multi-dimensional potential carried by modernity - perpetuated by the never fully actualized promise of freedom as its "groundless ground" (Heller 1999). Thus modernity remains on an "endless trial" (Kołakowski 1997) in which the actors involved face different possibilities and choose diverse ways of reaching the goal, simultaneously using the concept of modernity as a narrative, prospective framework (Jameson 2002). The practical dilemmas and intellectual debates concerning modernity have been so pluralized and abundant so far that one may ask if there is any point in revisiting the topic again. However, while working out our situated knowledge frames and playing out our own struggles with modernity, we found it highly relevant to again raise some of the core questions of the debates.

The capitalist West and its experience of rapid development, inaugurated by the Industrial Revolution, became a classic paradigm of modernization and the dominant path to follow for many societies in the forthcoming decades. The second half of $19^{\text {th }}$ century and (at least) first 
half of the $20^{\text {th }}$ were marked by radical concepts of social development. Projects fueled by it were often driven by the idea of catching up with the modernity. Radical ideologies propelled by the communist dream (Stoica 1997; Arnason 2000), technocratic lethal regimes, synthesizing regressive myths with mass destruction (Bauman 2013; Gentile 2003; Herf 1984), forceful industrializations on the peripheries (Leszczyński 2013), ideas of a united Europe (Delanty 2013; Therborn 1995), the welfare state (in both capitalist and socialist variants) (Hennock 2007; Hong 2014; Lebowitz 2012; Swaan 1988), and social tensions in real socialists countries (Habermas 1990) were all inseminated by its overwhelming influence. All of them could be legitimately considered as actualizations of the desire to become modern. All of them constitute rather amorphous constellations of multiple modernities (Eisenstadt 2002). In this regard Eisenstadt's concept might be a perspective allowing for a wider view integrating parochial instances into a general modern promise, and pushing further a coherent framework not separating modernity and modernization that far (Majewski 2009).

Modernity cannot be reduced to modernization projects. Apart from modernity-as-experience conceptualization ( Nycz and Zeidler-Janiszewska 2006; Wagner 2008), the major impulse propelling the empirical discourses of modernity is a particular state of mind, a collectively embedded vision of the self, "the attitude of modernity" (Foucault 1984). This attitude of constant self-reshaping, of mature reconstruction along the lines of a pre-defined ideal in order to overcome certain self-imposed inadequacies sparkles in countless localized pluralities. This reflexive attitude, turned into a down-to-earth paradigm of thinking, frames the reflexive modernization (Beck, Giddens, and Lash 1994; Beck, Bonss, and Lau 2003). All these modern scapes direct us to discourses constituting, solidifying and providing content to the imagined and practiced modernities. Thus, a historical overview of the interpretations and explanations thereof may be sought by a discursively oriented historical sociology of the modern which we aim at.

After all the humanities were saturated by this linguistic turn (Clark 2004), historical sociology also directed its steps towards intellectual and conceptual history (Wagner 2003) and rethought alliances with long lasting, albeit neglected, companions (Eder 2006). Researchers turned to discourse as the missing link between materiality of production (so stressed in Marxist approaches) and modern experience (Scott 1991). Just as the harbinger of this tendency - the history of labor - incorporated language and discourse in its entire methodological edifice, designed to scrutinize modern class subjectivities (for an overview see: 
Stedman Jones 1983; Joyce 1991; Steinberg 1999), so too we also aim at undertaking text-oriented historical research grounded in the general awareness of the indirect and language-mediated status of the primary sources. Along the lines drawn by discourse theory (Howarth 2000; Glynos and Howarth 2007), we believe that all existing objects and actions are meaningful due to a historically constituted set of rules. All human cultural activity is symbolically deployed and meaningful due to its being patterned like a language. Therefore, researchers should analyze the whole culture (and pluralized modernities) as language-like sign systems (Scott 2008).

The research framed in these terms seeks to reveal how social practices generate and question the discourses constituting the social reality. The very existence of these practices is conditioned by the fact that their systems of meaning are contingent and never exhaust the entire possible quantum of meanings in the given social context (Howarth 2000). Therefore, we study patterned deployments of meanings and their temporary stabilization concerning identities, assessment of natural and social processes and the like, in order to reveal "the words, metaphors and rhetorical conventions that (moderns - we add) used to think about their experience" (Sewell 1980, 11). Here lies the key to a critical revisit of the historical sociology of the modern.

While the classic argument known from Habermas' Der Philosophische Diskurs der Moderne (Habermas 1987) outlined the concept of modernity as a post-Kantian condition of not-immature, reason-driven, norm-grounded efforts to establish a certain polity and common life, we decided to follow another path. There is no question that politically speaking it was the French Revolution, which was the first catalyst of the political modernity (Baker 1990; Lefort 1988; Norval 2007; Sewell 2005). However, we refocus on the Marxist depiction of the unleashing of productive forces so as to indicate the basic conditions of the possibility for the modern imagery. The latter is marked by an intensified awareness of change and prospective hopes and fears. Only by keeping this in mind can one fully grasp the meaning of the problem posed by political modernity.

The massive change brought about by proliferating capitalism "melted all that is solid into air" (Marx and Engels 1975 vol. VI). The pre-modern mindset was no longer up-to-date, and the most conservative attitudes were no longer even close to the traditional self-obviousness of existence (Mannheim 1986). The space of experience ceased to be co-existential with the horizon of expectations (Koselleck 2004). Generations tossed by capitalist torsions sought to make themselves not only objects, but also subjects of modernity (Berman 1983). In the global history 
of multiple modernities (Eisenstadt 2002) these tensions were rendered in countless vernacular ways and fueled political struggles for centuries. The "simultaneity of the non-simultaneous" (Bloch 1977) in every instance of modernity made it a "multi-sited" phenomenon, the main locus of which was almost always imagined elsewhere, thus inducing a specific mode of prospective drive to keep up with (Majewski, Marzec, and Rejniak-Majewska 2014). How it was directed left an imprint on our concept of the contemporaneous.

Along with the demise of the pre-modern order a new radical contingency of the political was opened (Marchart 2007). It was no longer possible to refer the society to any permanent ground. And "this dissolution of the markers of certainty" (Lefort 1988) actualized itself as well in the most mundane issues being subject of modernization policies, rebuilding the common world. The challenge was intensified in the times of disruption of old orders and thresholds of social changes, as wars, revolutions and great crises constituted events inducing a certain activation of discursive order and dislocations (Laclau 1990). The opening of tomorrow and the questionable horizon of expectations triggered massive discursive responses in the struggle to understand and change the world.

This modern political problem may have triggered, as Agata Zysiak demonstrates, the fantasies of a utopian closure, accompanied by phantasmatic obstacles, which always prevent a fulfillment of utopia and threaten with an even more horrific dystopian vision. This was especially visible in the discourses concerning the paradigmatic form of modern polity, a dense force field with new populations and an emerging vision of the future - the rapidly industrialized capitalist city, also investigated by Kamil Śmiechowski. The vicissitudes of the modern condition were mediated and coped with discursively with the assistance of master signifiers. Some signifiers, as Atila Lukić and Gordan Maslov show in analyzing the concept of "transition", became "suturing" structures composed of various social experiences and political strategies. They are deployed so as to naturalize and universalize particular ideological options, concealing the contingency and imposing a temporary order of meaning.

One of the main signifying orders coping with modern ambiguity, strictly interwoven into capitalist development, is science involving 'purification', or a clear distinction between nature and culture, science and politics (Latour 2012). However, as Zachary Tavlin argues, already critical Victorians, Marx included, were aware of it and produced a discourse of 'modernity' that already recognized the failure of 'purification' as the result of expansive capitalism. 
These discontents triggered countless attempts to master human conduct. If any coherent vision of the future begin to predominate, it has a chance to be put into practice as certain form of modernization. The modernizing process, fueled by coherent, a priori visions, often led to neglect of the individual with all his or her singularity and irreplaceability. This problem also drew the critical attention of truly dialectical modernists such as Theodore W. Adorno and Max Horkheimer (2002). The Goethean tragedy of Philemon and Baucis (Berman 1983) was often reenacted when the complex modernization machine faced "human obstacles", often turning them into "causalities of history" (Thompson $1963,13)$. Such a clash, when state socialism aimed at reconstruction of the proletarian selves (Halfin 2011), is analyzed by Kaja Kaźmierska, who confronts individual workers' biographies with the cogwheels of socialist modernization.

Modernization also brought about a change in the form of life, for instance introducing a new kind of urban existence whereby new groups entered the public sphere and ushered new issue into the debate on the polity to be established. Kamil Śmiechowski investigates how the vision of cities in the Polish social imagination changed after 1905, when the masses took to the streets. As he argues, after the 1905 Revolution the urban intelligentsia lost the battle to lead the Polish urban discourse, but it won the battle for future, urban development of Poland.

Modernity also means also the activation of democratic tendencies (Rancière 2014), with waves of popular re-vindications grounded in the generalized idea of pan-human entitlement to self-determination and fulfillment (Rancière 1999). This "syllogism of emancipation" ushered the people to the streets for a struggle, claiming recognition and political visibility while simultaneously raising fears among those who profited heavily from the social stasis. This fear of the masses (Balibar, Stolze, and Giancotti 1989) propelled countless conservative reactions, neglecting rationality, political capability and even the humanity of "the crowds" (Jonsson 2013). Thus, one of the reactionary answers for democratic modern imaginary was a discourse of discipline and control, ameliorating the dark instincts of the an-archic crowd (Foucault 1995; Wagner 1994; Virilio 2006). In this context Wiktor Marzec examines the political discourse of National Democracy in Russian Poland at the turn of 19 th and $20^{\text {th }}$ centuries (see also Porter 1999). Another permutation of this problem - the oligarchic attempt to revive the class struggle from above resulted in a discourse concerning irrational claims of "homini sovietici" in the former Eastern Bloc (Buchowski 2006). This constituted a solid pillar for neoliberal transformation, new rounds of exclusions, 
and for garnering support for new elites championing the transformation. The ambiguous role of Polish social scientists in this matter is the subject of scrutiny of Wojciech Woźniak.

Having said the above, we are firmly convinced that there is a space for rethinking the different ideas of modernity. The question of what it means to be modern remains open. The authors and editors of this present issue have tried to find fresh interpretations of old problems, assuming that modernity is not a historical term but rather a constant challenge. Modernity exists not as an external project but as an individualized attitude which can be expressed only in social interrelations with others. This issue of Theoretical Practice seeks to undertake an archeology of modernity by investigating local intellectual and media discourses, vernacular attempts to modernize particular societies, and the conceptual changes brought about by definite historical events, understood as interventions into these interrelations. It should be noted that while introduced here in topical order, the articles in the journal are presented in approximate chronological order, narrating the subsequent dislocations posing milestones in our common struggle to be modern. As we are perfectly aware, such a strategy is a yet another truly modern attempt to narrate the contingency in a way which makes it intelligible for us, modern subjects. It is also a particular narrative of the editors listed below.

Our own situated knowledge frames, referred to in the opening paragraphs, stem from our investigation into the particular form of empirical discourse of modernity concerning the textile industrial city of Lodz. These are the focal points of the analysis in the research project: Four discourses of modernity - modernism of the periphery on the example of Lodz (19-20 ${ }^{\text {th }}$ centuries). This issue of Theoretical Practice includes some of the contributions written within the framework of this project. These investigations in turn are heavily embedded in situated experiences and personal struggles in particular places, exemplifying the Foucauldian "modern attitude" or will to improve (Li 2007).

Research for the core articles in this issue was possible thanks to the generous support of the Polish National Science Centre for the research project realized at University of Lodz, Poland, financed by research grant Opus 3, contracted as UMO-2011/03/B/HS6/01874. Project coordinator: Kaja Kaźmierska. Publication of this issue of Theoretical Practice is also part of the project realized at University of Lodz, Poland, financed by the Polish National Science Centre, research grant Opus 2 contracted as UMO-2011/03/B/HS6/01874. 


\section{Reference list:}

Arnason, Johann P. 2000. "Communism and Modernity." Daedalus 129(1): 61-90.

Baker, Keith Michael. 1990. Inventing the French Revolution: Essays on French Political Culture in the Eighteenth Century. Ideas in Context. Cambridge [England]-New York: Cambridge University Press.

Balibar, Etienne, Ted Stolze, and Emilia Giancotti. 1989. "Spinoza, the Anti-Orwell: The Fear of the Masses.” Rethinking Marxism 2(3): 104-39. doi:10.1080/08935698908657878.

Bauman, Zygmunt. 2013. Modernity and the Holocaust. Hoboken: Wiley. Beck, Ulrich, Wolfgang Bonss, and Christoph Lau. 2003. "The Theory of Reflexive Modernization: Problematic, Hypotheses and Research Programme." Theory, Culture \& Society 20(2): 1-33. doi:10.1177/026 3276403020002001.

Beck, Ulrich, Anthony Giddens, and Scott Lash. 1994. Reflexive Modernization: Politics, Tradition and Aesthetics in the Modern Social Order. Stanford, California: Stanford University Press.

Berman, Marshall. 1983. All That Is Solid Melts into Air: The Experience of Modernity. London: Verso.

Bloch, Ernst. 1977. "Nonsynchronism and the Obligation to Its Dialectics." Translated by Mark Ritter. New German Critique, 11: 22-38. Buchowski, Michał. 2006. "The Specter of Orientalism in Europe: From Exotic Other to Stigmatized Brother." Anthropological Quarterly 79(3): 463-82.

Clark, Elizabeth A. 2004. History, Theory, Text Historians and the Linguistic Turn. Cambridge, Mass.: Harvard University Press.

Delanty, Gerard. 2013. Formations of European Modernity: A Historical and Political Sociology of Europe. Basingstoke: Palgrave Macmillan.

Eder, Franz, (ed.). 2006. Historische Diskursanalysen: Genealogie, Theorie, Anwendungen. 1. Aufl. Wiesbaden: VS Verlag für Sozialwissenschaften. Eisenstadt, Shmuel N., (ed.). 2002. Multiple Modernities. New Brunswick, N.J: Transaction Publishers.

Flatley, Jonathan. 2008. Affective Mapping: Melancholia and the Politics of Modernism. Cambridge, Mass: Harvard University Press.

Foucault, Michel. 1984. "What Is Enlightenment." In The Foucault Reader, edited by Paul Rabinow, 1st ed. New York: Pantheon Books.

Foucault, Michel. 1995. Discipline and Punish: The Birth of the Prison. Translated by Alan Sheridan, 2nd Vintage Books ed. New York: Vintage Books.

Gentile, Emilio. 2003. The Struggle for Modernity: Nationalism, Futurism, 
and Fascism. Italian and Italian American Studies. Westport, Conn: Praeger. Glynos, Jason, and David Howarth. 2007. Logics of Critical Explanation in Social and Political Theory. Routledge Innovations in Political Theory 26. London-New York: Routledge.

Habermas, Jürgen. 1987. The Philosophical Discourse of Modernity: Twelve Lectures. Translated by Frederick G Lawrence. Cambridge, Mass.: MIT Press.

Habermas, Jürgen. 1990. "What Does Socialism Mean Today? The Rectifying Revolution and the Need for New Thinking on the Left." Translated by Ben Morgan. New Left Review, 183: 3-21.

Halfin, Igal. 2011. Red Autobiographies: Initiating the Bolshevik Self. Seattle: University of Washington Press.

Heller, Agnes. 1999. A Theory of Modernity. Malden, Mass: Blackwell Publishers.

Hennock, E.P. 2007. The Origin of the Welfare State in England and Germany, 1850-1914: Social Policies Compared. Cambridge-New York: Cambridge University Press.

Herf, Jeffrey. 1984. Reactionary Modernism: Technology, Culture, and Politics in Weimar and the Third Reich. Cambridge [Cambridgeshire]-New York: Cambridge University Press.

Hong, Young-Sun. 2014. Welfare, Modernity, and the Weimar State. Princeton: Princeton University Press.

Horkheimer, Max, and Theodor W. Adorno. 2002. Dialectic of Enlightenment: Philosophical Fragments. Edited by Gunzelin Schmid Noerr. Translated by Edmund Jephcott. Cultural Memory in the Present. Stanford, California: Stanford University Press.

Howarth, David R. 2000. Discourse: Concepts in the Social Sciences. Buckingham [England]-Philadelphia, PA: Open University Press.

Jameson, Fredric. 2002. A Singular Modernity: Essay on the Ontology of the Present. London-New York: Verso.

Jonsson, Stefan. 2013. Crowds and Democracy: The Idea and Image of the Masses from Revolution to Fascism. Columbia Themes in Philosophy, Social Criticism, and the Arts. New York: Columbia University Press. Joyce, Patrick. 1991. Visions of the People: Industrial England and the Question of Class, 1848-1914. Cambridge-New York: Cambridge University Press. Kołakowski, Leszek. 1997. Modernity on Endless Trial. Chicago: University of Chicago Press.

Koselleck, Reinhart. 2004. Futures Past: On the Semantics of Historical Time. New York: Columbia University Press.

Laclau, Ernesto. 1990. New Reflections on the Revolution of Our Time. Phronesis. London-New York: Verso. 
Latour, Bruno. 2012. We Have Never Been Modern. Translated by Catherine Porter. Cambridge, Mass.: Harvard University Press. Lebowitz, Michael A. 2012. The Contradictions of "Real Socialism" the Conductor and the Conducted. New York: Monthly Review Press. Lefort, Claude. 1988. Democracy and Political Theory. Cambridge, UK: Polity Press in association with Basil Blackwell, Oxford, UK.

Leszczyński, Adam. 2013. Skok w nowoczesnośc: Polityka wzrostu w krajach peryferyjnych 1943-1980. Warszawa: Instytut Studiów Politycznych PAN, Wydawnictwo Krytyki Politycznej.

Li, Tania. 2007. The Will to Improve Governmentality, Development, and the Practice of Politics. Durham: Duke University Press.

Majewski, Tomasz. 2009. "Modernizmy i ich losy." In Rekonfiguracje modernizmu: Nowoczesnosc i kultura popularna. Warszawa: Wydawnictwa Akademickie i Profesjonalne.

Majewski, Tomasz, Wiktor Marzec, and Agnieszka Rejniak-Majewska. 2014. "Migracje intelektualne: Paradygmaty teorii i materializm biograficzny." In Migracje modernizmu: Nowoczesność i uchodźcy. ŁódźWarszawa: Stowarzyszenie Topografie, Narodowe Centrum Kultury.

Mannheim, Karl. 1986. Conservatism: A Contribution to the Sociology of Knowledge. International Library of Sociology. London-New York: Routledge \& Kegan Paul.

Marchart, Oliver. 2007. Post-Foundational Political Thought: Political Difference in Nancy, Lefort, Badiou and Laclau. Edinburgh: Edinburgh University Press.

Marx, Karl, and Friedrich Engels. 1975. Karl Marx, Frederick Engels: Collected Works. New York: International Publishers.

Norval, Aletta J. 2007. Aversive Democracy: Inheritance and Originality in the Democratic Tradition. Cambridge-New York: Cambridge University Press.

Nycz, Ryszard, and Anna Zeidler-Janiszewska, (eds.). 2006. Nowoczesność jako doświadczenie. Kraków: Universitas.

Porter, Brian. 1999. "Democracy and Discipline in Late NineteenthCentury Poland.” The Journal of Modern History 71(2): 346-93.

Rancière, Jacques. 1999. Disagreement: Politics and Philosophy. Translated by Julie Rose. Minneapolis: University of Minnesota Press.

Rancière, Jacques. 2014. Hatred of Democracy. Translated by Steve Corcoran.

Scott, Joan W. 1991. "The Evidence of Experience.” Critical Inquiry 17(4): 773-797.

Scott, Joan W. 2008. "On Language, Gender, and Working-Class History." International Labor and Working-Class History 31 (December): 
1. doi:10.1017/S0147547900004063.

Sewell, William. 1980. Work and Revolution in France: The Language of Labor from the Old Regime to 1848. Cambridge-New York: Cambridge University Press.

Sewell, William. 2005. Logics of History: Social Theory and Social Transformation. Chicago Studies in Practices of Meaning. Chicago: University of Chicago Press.

Stedman Jones, Gareth. 1983. Languages of Class: Studies in English Working Class History, 1832-1982. Cambridge-New York: Cambridge University Press.

Steinberg, Marc W. 1999. Fighting Words: Working-Class Formation, Collective Action, and Discourse in Early Nineteenth-Century England. Ithaca, N.Y: Cornell University Press.

Stoica, Augustin. 1997. "Communism as a Project for Modernization: The Romanian Case.” Polish Sociological Review 120: 313-331.

Swaan, Abram de. 1988. In Care of the State: Health Care, Education, and Welfare in Europe and the USA in the Modern Era. Europe and the International Order. Cambridge, U.K.: Polity Press.

Therborn, Göran. 1995. European Modernity and beyond the Trajectory of European Societies, 1945-2000. London-Thousand Oaks, Calif.: Sage Publications.

Thompson, Edward P. 1963. The Making of the English Working Class. Vintage Giant. New York: Vintage Books.

Virilio, Paul. 2006. Speed and Politics. 2006 ed. Semiotext(e) Foreign Agents Series. Los Angeles, CA: Semiotext(e).

Wagner, Peter. 1994. A Sociology of Modernity: Liberty and Discipline. London-New York: Routledge.

Wagner, Peter. 2003. "As Intellectual History Meets Historical Sociology." In Handbook of Historical Sociology. London-Thousand Oaks, Calif: Sage. Wagner, Peter. 2008. Modernity as Experience and Interpretation: A New Sociology of Modernity. Cambridge, UK-Malden, MA: Polity. 


\section{Citation:}

J. Burski, W. Marzec, A. Zysiak, Toward a discursively oriented historical sociology of the modern, „Praktyka Teoretyczna” nr 3(13)/2014, http:// www.praktykateoretyczna.pl/ PT_nr13_2014_Archeologies/01. Wstep. pdf, DOI 10.14746/pt.2014.3.1 (date).

DOI: $10.14746 / p t .2014 .3 .1$

Authors: Jacek Burski, Wiktor Marzec, Agata Zysiak

Title: Toward a discursively oriented historical sociology of the modern

Keywords: modernity, modernization, the political, historical sociology, discourse analysis 


\section{we "other victorians" yet another time}


